\section{Check for updates}

\section{AUTHORS:}

Annette M. Amakali' iD

Ali Halajian² (iD

Margit R. Wilhelm 1 (ID)

Martin Tijpute

Richard Heckmann ${ }^{3}$

Wilmien Luus-Powell ${ }^{2}$ iD

\section{AFFILIATIONS:}

Department of Fisheries and Aquatic Sciences, University of Namibia, Henties Bay, Namibia

2DSI-NRF SARChl Chair (Ecosystem Health), Department of Biodiversity, University of Limpopo, Polokwane, South Africa

${ }^{3}$ Department of Biology, Brigham Young University, Provo, Utah, USA

\section{CORRESPONDENCE TO:}

Ali Halajian

EMAIL:

ali_hal572002@yahoo.com

DATES:

Received: 31 0ct. 2020

Revised: 29 July 2021

Accepted: 01 Oct. 2021

Published: 27 Jan. 2022

\section{HOW TO CITE:}

Amakali AM, Halajian A, Wilhelm

MR, Tjipute M, Heckmann R, Luus-

Powell W. Selected parasites of

silver kob (Argyrosomus inodorus)

(Actinopterygii: Sciaenidae) from

(Actinoptric

northern Namibia. S Afr J Sci.

2022;118(1/2), Art. \#9139. https://

doi.org/10.17159/sajs.2022/9139

\section{ARTICLE INCLUDES:}

囚 Peer review

$\square$ Supplementary material

\section{DATA AVAILABILITY:}

$\square$ Open data set

$\square$ All data included

冈 On request from author(s)

$\square$ Not available

$\square$ Not applicable

\section{EDITORS:}

Bettine van Vuuren iD

Sydney Moyo iD

\section{KEYWORDS:}

Monogenea, Acanthocephala, mariculture, Atlantic Ocean, fish parasites

\section{FUNDING:}

University of Namibia; DSI-NRF SARChl (grant no. 101054)

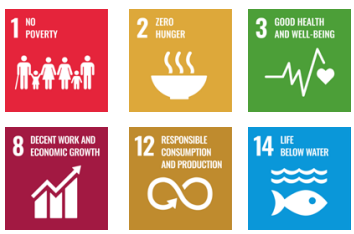

(C) 2022. The Author(s). Published under a Creative Commons Attribution Licence.

\title{
Selected parasites of silver kob (Argyrosomus inodorus) (Actinopterygii: Sciaenidae) from northern Namibia
}

\begin{abstract}
The present study reports five metazoan parasites recorded from silver kob (Argyrosomus inodorus). Five fish were collected monthly $(n=55)$ for 11 months in 2017-2018 (excluding July 2017) using conventional angling gear in Toscanini, Mile 108 and Henties Bay, northern Namibia. Fish were examined individually for ecto- and endo-parasites. Photomicrographs, drawings and measurements of parasites were made using a camera lucida and calibrated eyepiece of an Olympus (BX50) compound microscope and/or a Zeiss (Discovery V8) camera calibrated on a Leica dissecting microscope. Amongst species found, monogeneans including Diplectanum sciaenae van Beneden \& Hesse, 1863, two species of Calceostoma van Beneden, 1858, one species of Sciaenacotyle Mamaev, 1989 and one acanthocephalan Corynosoma australe Johnston, 1937 were found and are reported here. This is the first study of parasites found from silver kob of the Atlantic Ocean. Silver kob has potential to be used as a mariculture species. In addition to mariculture, information obtained from this study may also be used as a baseline for stock structure and biological tagging.

\section{Significance:}

- Silver kob has potential to be used as a mariculture species. Information obtained from this study will therefore form awareness to future mariculture silver kob farmers in terms of parasites that can infest and infect silver kob, hence making it possible to apply specific prevention and control measures. In addition to mariculture, results obtained from this study may be used as a baseline for biological tagging for stock structure assessment using parasites.
\end{abstract}

\section{Introduction}

Silver kob, Argyrosomus inodorus Griffiths \& Heemstra, 1995, Actinopterygii, Perciformes, Sciaenidae, commonly known as kabeljou in southern Africa, has a short history of culture in southern Africa. ${ }^{1,2}$ Its congeners, A. hololepidotus Lacepède, 1801 (Madagascar meagre), A. japonicus Temminck \& Schlegel, 1843 (dusty kob/ mulloway) and $A$. regius Asso, 1801 (meagre) have been cultured successfully for many years throughout the world, including in South Africa. ${ }^{3-10}$ The Namibian marine aquaculture (mariculture) is dominated by shellfish (oyster and abalone). There is need to diversify the sector to ensure wide specialisation and make it more economically viable (stable). There are ongoing investigations into the aquaculture of some important finfish species (of which kob is one species of interest). Studies are looking into the captive propagation, larval rearing, feeding and disease (including parasites) aspects of the kob species. Currently in Namibia, silver kob is one of the most important species caught by shore anglers and ski-boat anglers in water shallower than $20 \mathrm{~m} \cdot{ }^{11}$

Characteristics of silver kob - such as its robust growth, ability to spawn in captivity as well as its market value - make it one of the fish species suitable for mariculture. ${ }^{5,6,12}$ However, various diseases, including parasitic infections, pose a threat to fish cultivation, to the success of mariculture, as well as to the people that depend on it for a basic income. In many instances, fish health is not prioritised until extreme impacts are observed, which means the opportunity to manage and control parasites and diseases at the source is missed. Most farmers tend to react to large outbreaks rather than preventing or managing infections, most likely because of insufficient information on the ecology of pathogenic parasites, their prevention and control. ${ }^{13}$ The diseases and specific identity of the parasites that are infecting cultured fish are rarely known and very few parasite species, classified only to their genera, are recorded. ${ }^{14}$

External and internal clinical signs triggered by pathogens depend on the host species, fish age and stage of the disease. ${ }^{15}$ Parasites generally do not kill their hosts, but some severely stress fish to the point of biological and economical concern. ${ }^{16}$ High intensities of ecto-parasites cause excess mucus secretion, loose scales, dermis injuries such as haemorrhages, open sores, ulcers exposing connective and muscle tissues, and osmotic problems affecting respiratory functions. ${ }^{16}$ Consequently, damaged skin and gills make the fish host more susceptible to secondary infections, possibly from viruses, bacteria and other microorganisms that may also contribute to mortalities. ${ }^{17}$ Martins et al. ${ }^{18}$ and Kotob et al. ${ }^{19}$ reviewed impacts of different secondary infections, also called co-infections, on fish species.

In the wild, parasites have been used as a biotic force capable of determining the biodiversity of fish communities..$^{20}$ Parasites can regulate the population size of some fish species based on their susceptibility. If the host is the predator, parasite infestation causes lack of appetite, thereafter increasing the number of prey and, as most prey are herbivores, further decreasing the plant community. In addition, parasites can indirectly modify the functional importance of the host species by altering the host's phenotype (morphology, colouration and behaviour) which may influence the availability and scarcity of resources for other species. This could make the host, or part of the host's body, available as a resource to other organisms. ${ }^{20}$

The culture of kob is being considered in Namibia and therefore parasites that infect it are being investigated. 


\section{Known parasites of kob}

\section{Diplectanum Diesing, 1858}

Diplectanum, a genus of monopisthocotylean monogeneans, is the largest genus in the Diplectanidae and consists of over 80 species. ${ }^{21,22}$ In nature, species of Diplectanum are not highly pathogenic parasites; under adverse conditions, however, they can multiply and have detrimental effects on their hosts. ${ }^{9}$ There have been several reports associating monogeneans with increased fish mortalities in aquaculture, mostly because cultured fish are grown in high densities and handling procedures result in fish stress.

\section{Calceostoma van Beneden, 1858}

Species in the genus Calceostoma have been reported from the gills and skin of fish all over the world, including Australia and southern Africa. ${ }^{3,21}$ The genus comprises eight species of which only two described were available for use in the present study: Calceostoma herculanea Euzet \& Vala, 1975 and Calceostoma glandulosum Johnston \& Tiegs, 1922, synonym Calceostoma calceostoma Wagener, 1857 by Williams ${ }^{3}$. They are not highly pathogenic in nature, but can cause haemorrhages if they intensify in a mariculture set-up.

\section{Sciaenacotyle Mamaev, 1989}

Mycrocotylids are recognisable by their possession of large numbers of clamps that are relatively simple and lack accessory sclerites. ${ }^{5}$ To date, the genus Sciaenacotyle consists of only two documented species: Sciaenacotyle panceri Sonsino, 1891 and Sciaenacotyle sciaenacola Murray, 1932. There have been reports of these blood-feeding species affecting the gills of sciaenids shi drum (Umbrina cirrosa Linnaeus, 1758) in Tunisia ${ }^{23}$, congeners meagre, Argyrosomus regius in Sardinia ${ }^{6}$ and mulloway, Argyrosomus japonicus in Australia ${ }^{7}$. They are predominantly characterised by the nature of the genital armature. Their lengths may vary depending on the state of the contraction of the body during fixation or observation and the size of the host, as parasites on larger hosts grow faster than those infesting smaller hosts. ${ }^{5}$ In addition, temperature may also impact length and clamp size.

The parasites collected during the current study slightly differ from these two Sciaenacotyle species and are briefly described here.

\section{Corynosoma Lühe, 1904}

Acanthocephala is a phylum that is closely associated with the Cestoda phylum. ${ }^{24}$ They are an integral component of the parasite fauna of pinnipeds. Corynosoma Lühe, 1904 consist of numerous species that use cetaceans and fish as intermediate hosts, and pinnipeds and fisheating birds as definitive hosts. ${ }^{24-26}$ Acanthocephalans are characterised by a thorny anterior termed 'proboscis' that serves as an attachment organ and 'drills' firmly into the walls of the intestine and stomach of the host. The proboscis drilling causes damage and changes to the tissues, exposing the tissues to other secondary infections and increasing the host's susceptibility to diseases and infection. ${ }^{27}$ Acanthocephalans lack a mouth and digestive tract. They absorb their nutrients directly through their body surface. Adult acanthocephalans usually live in the lumen of the digestive tract only, but sometimes they bore through the walls of the digestive tract and come to lie in the abdominal cavity. ${ }^{28}$

Parasites have also been used as biological tags in stock identification in marine fish according to the principle explained by MacKenzie et al. ${ }^{29}$ Fish become infected or infested with a particular parasite only when they come within the endemic area of that parasite - the endemic area being the geographical region in which transmission of the parasite can take place. If infected fish are found outside the endemic area, it is inferred that these fish had been within that area at some time in their past history. Parasite communities differ substantially among fish hosts even in the same geographical area. ${ }^{30}$ Parasites, especially monogeneans, are host specific, and this specificity can be so strict that one parasite species may be restricted to only one fish species or genus. ${ }^{17}$ The information on the life span of the parasite in that particular host will allow the researcher to estimate the maximum time since the fish could have become infected, that is, the maximum time since it left the endemic area.

Information on parasites infecting silver kob is scarce. Stewart ${ }^{21}$ and Christison et al. ${ }^{31}$ also reported on Calceostoma sp. and Diplectanum sp. from the gills of $A$. inodorus in South Africa. Kotungondo has found species of the monogenean Sciaenacotyle panceri Sonsino, 1891 on the gills of the Namibian silver kob, Argyrosomus inodorus (Kotungondo BCC 2014, written communication, November 24). To the best of our knowledge, there is no previous documented study on parasites of silver

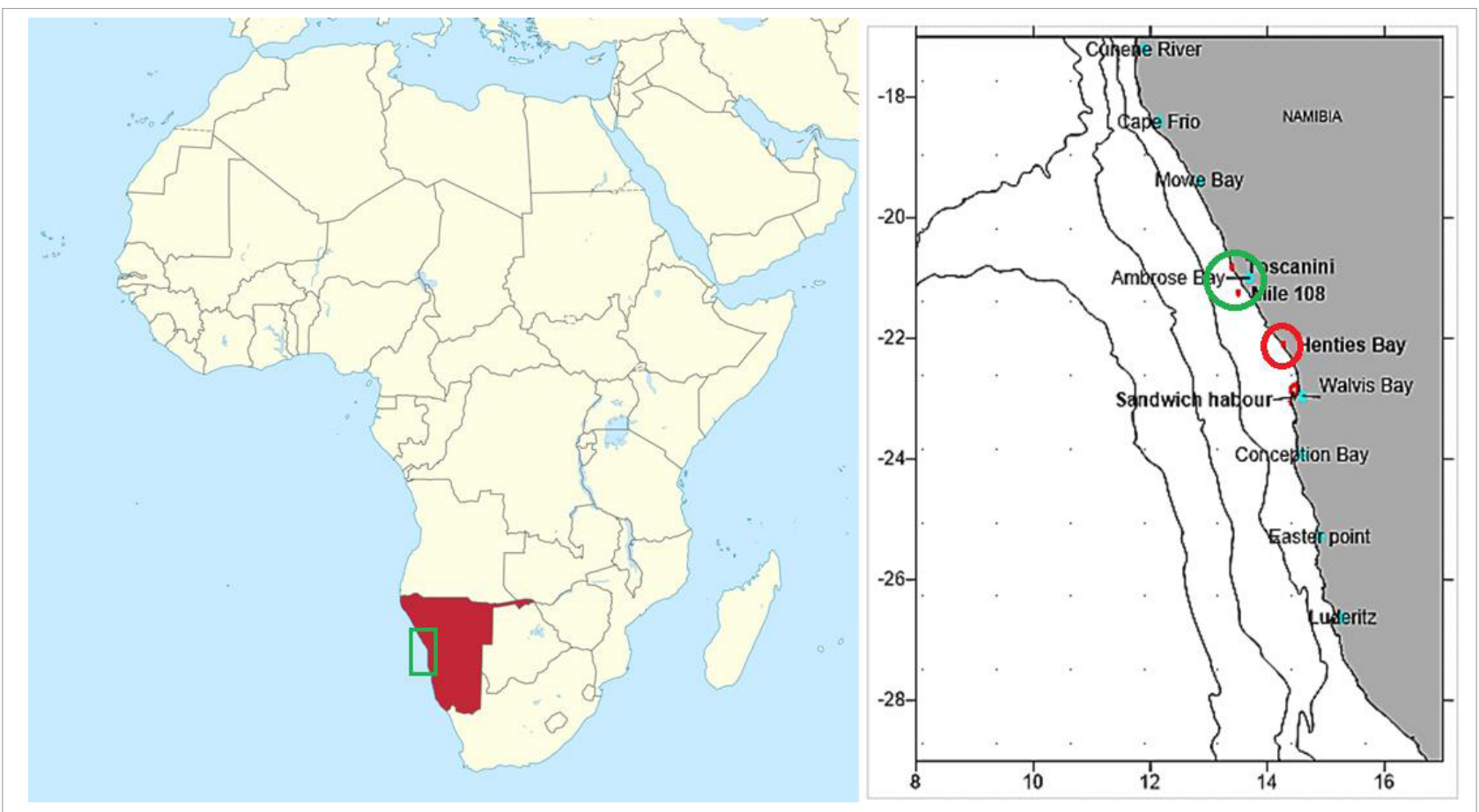

Source: Map on the left: https://commons.wikimedia.org/wiki/File:Namibia_in_Africa_(-mini_map_-rivers).svg

Figure 1: Sampling area (Toscanini and Mile 108 on the Namibian coast) of silver kob indicated by the green circle and secondary sampling area indicated by the red circle. 
kob in Namibia, although there have been a few reports on parasites from its congeners globally. We report on metazoan parasites from silver kob caught in northern Namibia.

\section{Materials and methods}

A total of 55 silver kob were collected over 11 months (June 2017, and August 2017 to May 2018), with 5 fish sampled and examined each month. Of these, 49 silver kob were caught using conventional angling gear at Toscanini and Mile 108, both sites within the Skeleton Coast Park, at about $20^{\circ} 50^{\prime} \mathrm{S}, 13^{\circ} 25^{\prime} \mathrm{E}$ and $21^{\circ} 49^{\prime} \mathrm{S}, 13^{\circ} 25^{\prime} \mathrm{E}$, respectively (Figure 1). Six silver kob were caught by local anglers in Henties Bay $\left(22.1^{\circ} \mathrm{S}\right.$ and $14.3^{\circ} \mathrm{E}$ ) (Figure 1).

Fish were sacrificed by a single cut through the spinal cord. The skin, fins, eyes and gastrointestinal organs were examined for parasites according to the procedure of Noga ${ }^{32}$. All parasites were identified and counted. In total, 28 species were identified ${ }^{33}$, but for the present study only 5 species are listed and described. Whole mount preparations were made for monogeneans using glycerine ammonium picrate solution on microscope slides and some were preserved in vials with $70 \%$ ethanol. Nail varnish was used to seal the whole mounts.

Photomicrographs, drawings and measurements of parasites were made using a camera lucida and calibrated eyepiece of an Olympus (BX50) compound microscope or a Zeiss (Discovery V8) camera calibrated on a Leica dissecting microscope. All measurements are in micrometres $(\mu \mathrm{m})$ unless otherwise indicated. In the descriptions, the initial number is the mean measurement followed by the minimum and maximum measurements (range) in parentheses and finally the number of specimens measured for that particular category $(n=\mathrm{x})$.

For scanning electron microscopy, specimens were dehydrated through a series of ethanol $(70,80,90,100$, and $100 \%)$ for $1 \mathrm{~h}$ each, followed by immersion in hexamethyldisilazane. After complete evaporation of hexamethyldisilazane, the specimens were sputter coated with goldpalladium in a Polaron SC7640 sputter coater. Specimens were then kept in a fume cupboard so that no dust fell on them while waiting for evaporation of hexamethyldisilazane. The specimens were examined using a LEO VP 1540 microscope at $10 \mathrm{kV}$.

\section{Ethics approval}

The study was approved by the University of Namibia's Research and Publication Committee.

\section{Results}

During this study, we analysed five helminths identified from silver kob (A. inodorus). Some effects of these parasites on their hosts were obvious and profound (damage causing secondary infections, decreased fish quality, reduced growth, etc.) (Table 1).

\section{Monogeneans}

Diplectanum sciaenae van Beneden and Hesse, 1863

Host: Argyrosomus inodorus Griffiths and Heemstra, 1995 Site: Skin, gills

Locality: Henties Bay, Mile 108 and Toscanini, Namibia

\section{Description:}

Eight whole-mount adult specimens were measured (Diplectanidae; Diplectanum sciaenae; Figure 2). Long and slender with total body length measuring $735 \mu \mathrm{m}$ (436-943) $(n=8)$ and mid-body width of $185 \mu \mathrm{m}$ $(117-250)(n=8)$ (Figure 2a). The haptor (Figure $2 b)$, which measured $252 \mu \mathrm{m}(198-310)(n=8)$ total length, consists of a lip-shaped median bar (Figure 2c), which measured $107 \mu \mathrm{m}$ (97-134) $(n=8)$ total length, $23 \mu \mathrm{m}(20-27)(n=8)$ maximum width (i) and $15 \mu \mathrm{m}$ (12-17) $(n=8)$ minimum width (ii) at centre. The haptor has two transverse bars (Figure 2d) on either side of the median bar with total length of $95 \mu \mathrm{m}(81-122)$ $(n=8)$ that mostly meet midway from each side of the median bar, but do not overlap each other. In rare cases, the transverse bars were shifted $1 / 4^{\text {th }}$ from the median bars toward the ends. At the end of each transverse bar lies a pair of curved-in hamuli consisting of a ventral (Figure 2e) and dorsal (Figure 2f) hamulus. The ventral hamulus has a long deep root and a short superficial root with the following dimensions: length (i) 70 $\mu \mathrm{m}$ (64-74) (n=8); length (ii) $65 \mu \mathrm{m}$ (59-67) $(n=8)$; length (iii) $37 \mu \mathrm{m}$ (35-40) $(n=8)$, length (iv) $28 \mu \mathrm{m}(25-33)(n=8)$. The dorsal hamulus has a long deep-root and a poorly developed superficial root: length (i) $62 \mu \mathrm{m}(55-65)(n=8)$ and length (ii) $57 \mu \mathrm{m}(52-60)(n=8)$. Just below the median bar, the squamodiscs (Figure 2b) measure $161 \mu \mathrm{m}$ (124222) $(n=8)$ total length and $140 \mu \mathrm{m}(109-187)(n=8)$ maximum width with $36 \mu \mathrm{m}(32-38)(n=8)$ concentric divergent rows.

The male copulatory organ (MCO) (Figure $2 \mathrm{~g}$ ) is small with $55 \mu \mathrm{m}$ (50-76) $(n=8)$ total length. The MCO widens at the base and has a spiral end encircling the tip end. The sclerotised canal (Figure $2 \mathrm{~h}$ ) at the conspicuous prostatic reservoir measures $29 \mu \mathrm{m}(26-40)(n=8)$ total length and $9 \mu \mathrm{m}(6-12)(n=8)$ maximum width. The sclerotised canal is sharply curved as described for $D$. sciaenae previously. ${ }^{8,9}$

\section{Calceostoma glandulosum Johnston and Tiegs, 1922}

Host: Argyrosomus inodorus Griffiths and Heemstra, 1995 Site: Gills, skin

Locality: Henties Bay, Mile 108 and Toscanini, Namibia

\section{Description:}

Four whole-mount adult specimens were measured. Body elongated, total body length measures $6250 \mu \mathrm{m}(4200-8000) \quad(n=4)$ and maximum body width $1000 \mu \mathrm{m}$ (900-1100) (Figure 3). Hood-like lappet (Figure 3e) with irregular margins at anterior end measuring $1225 \mu \mathrm{m}$ (200-1900) $(n=4)$ maximum width. Two pairs of small conspicuous eyespots just anterior to the pharynx. The pharynx (Figure 3e) measures $290 \mu \mathrm{m}(234-322)(n=4)$ total length and $271 \mu \mathrm{m}(227-342)(n=4)$ maximum width. The haptor consists of a median bar with $\mathrm{t}$-shaped

Table 1: $\quad$ Five parasite species found on Namibian silver kob collected from Toscanini, Mile 108 and Henties Bay from June 2017 to May 2018 and their possible pathogenicity

\begin{tabular}{|c|c|c|c|}
\hline Class & Genus/Order & Species & Pathogenicity \\
\hline \multicolumn{4}{|c|}{ Ecto-parasites } \\
\hline \multirow{3}{*}{ Monogenea } & Diplectanum Diesing, 1858 & D. sciaenae van Beneden \& Hesse, 1863 & \multirow{3}{*}{$\begin{array}{l}\text { Not pathogenic but can have effects on fish quality. Could } \\
\text { also act as vectors of viruses and bacteria. }\end{array}$} \\
\hline & Calceostoma van Beneden, 1858 & C. glandulosum Johnston \& Tiegs, 1922 & \\
\hline & Sciaenacotyle Mamaev, 1989 & Sciaenacotyle sp. & \\
\hline \multicolumn{4}{|c|}{ Endo-parasites } \\
\hline Monogenea & Calceostoma van Beneden, 1858 & Calceostoma sp. & Unknown \\
\hline Palaeacanthocephala & Corynosoma Lühe, 1904 & C. australe Johnston, 1937 & Damage to fish host, causes secondary infections \\
\hline
\end{tabular}




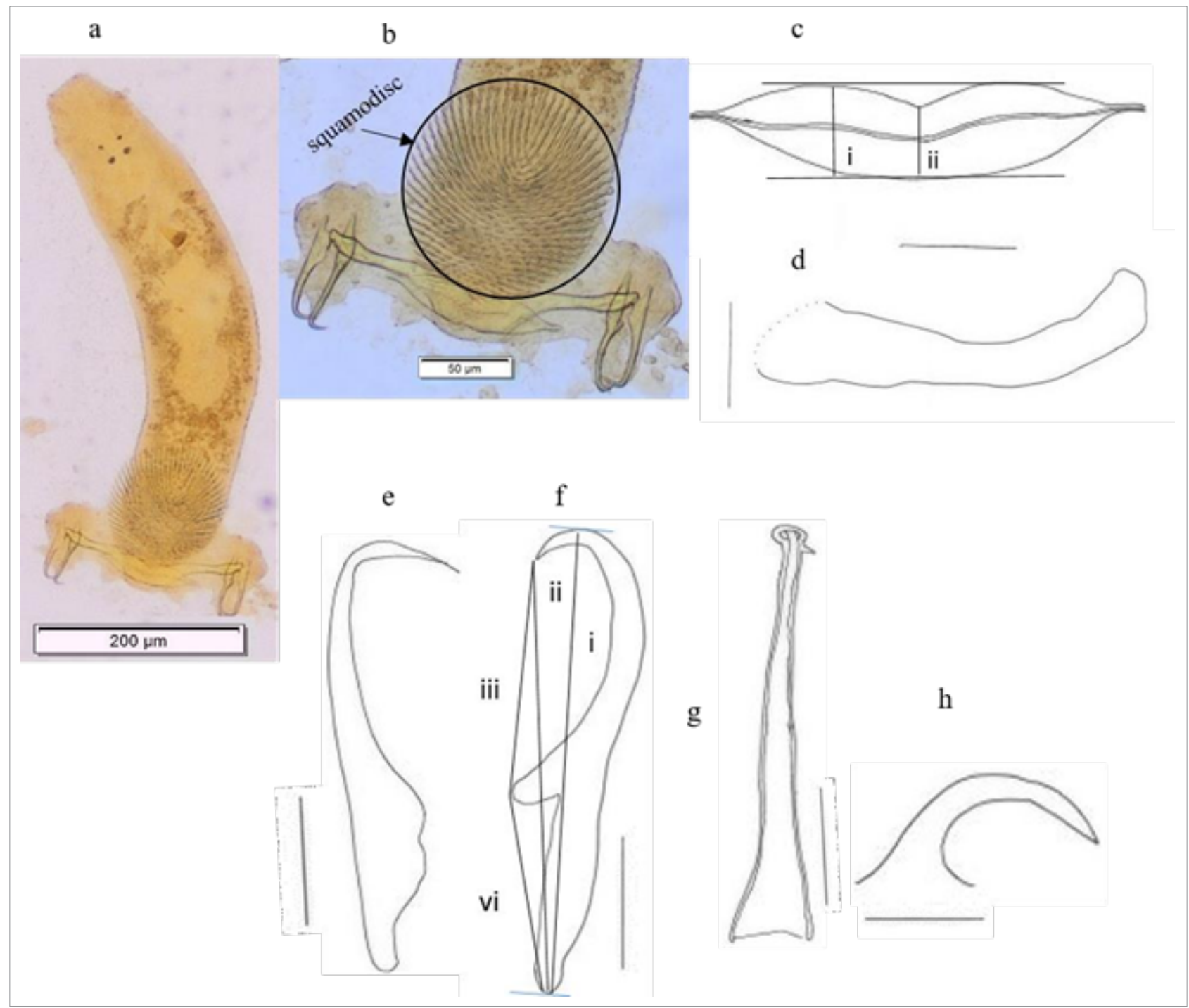

Scale bars: $20 \mu m(c-h)$

Figure 2: Diplectanum sciaenae van Beneden \& Hesse, 1863 from the gills of silver kob. (a) Diplectanum sciaenae whole mount. (b) Haptor with squamodiscs and hamuli. (c) Median bar (lengths (i) and (ii)). (d) Transverse bar. (e) Ventral bar/hamulus. (f) Dorsal bar/hamulus with measurements (lengths i-iv). (g) Male copulatory organ. (h) Sclerotised canal.

posterior end and a paddle-shaped anterior end, which is associated with a pair of hamuli (Figure 3a-c). The haptor measures $225 \mu \mathrm{m}$ (220-233) $(n=4)$ and $50 \mu \mathrm{m}(44-53)(n=4)$ anterior end 'T' width. The hamulus (Figure 3c) measures $200 \mu \mathrm{m}(188-213)(n=4)$. The MCO (Figure 3d) has a total length (i) of $189 \mu \mathrm{m}(179-195)(n=4)$; length (ii) of $165 \mu \mathrm{m}$ $(159-171)(n=4)$ and width of $24 \mu \mathrm{m}(21-26)(n=4)$.

\section{Calceostoma sp.}

Host: Argyrosomus inodorus Griffiths and Heemstra, 1995

Site: Stomach

Locality: Henties Bay, Mile 108 and Toscanini, Namibia

\section{Description:}

These species were found in nine $A$. inodorus hosts throughout the study and from all three study areas. Each host had either one or two Calceostoma sp. parasites. They were mostly found attached at the threshold walls of the stomach rather than in the middle of the stomach itself. Three whole-mount specimens were measured. Body slimmer and darker in colour compared to $C$. glandulosum. Total body length $4633 \mu \mathrm{m}$ $(2900-6900)(n=3)$ and $567 \mu \mathrm{m}(400-800)(n=3)$ maximum body width (Figure 4). Lappet not hood-like but less developed $(2000 \mu \mathrm{m})$ $(n=1)$. This could be an adaptation mechanism to allow it to attach properly to the host stomach walls. Pharynx (see Figure 3e) length 303 $\mu \mathrm{m}(294-312)(n=2)$ and $276 \mu \mathrm{m}(261-292)(n=2)$ pharynx maximum width. The median bar (Figure 4e) measures $147 \mu \mathrm{m}$ (133-172) $(n=3)$ length, $36 \mu \mathrm{m}$ (33-39) $(n=3)$ anterior end ' $V$ ' width and $144 \mu \mathrm{m}(129-$ 159) $(n=3)$ hamulus length, slightly curved in at the tips (Figure 4c). The MCO (Figure $4 \mathrm{~b}$ ) has a coiled anterior end and a thin posterior end and measures $184 \mu \mathrm{m}$ (173-202) $(n=3)$ length (i), $139 \mu \mathrm{m}(125-153)$ $(n=3)$ length (ii) and $13 \mu \mathrm{m}(12-13)(n=3)$ width.

\section{Sciaenacotyle sp. Mamaev, 1989}

Host: Argyrosomus inodorus Griffiths and Heemstra, 1995 Site: Gills Locality: Henties Bay, Mile 108 and Toscanini, Namibia

\section{Description:}

Thirteen whole-mount specimens were measured. Elongated body measures $8123 \mu \mathrm{m}(4000-11400)(n=13)$ total body length and $1208 \mu \mathrm{m}(500-1800) \quad(n=13)$ maximum body width (Figure 5$)$. Possesses a triangular posterior haver that occupies about a third of the total body with numerous clamps (Figure $5 f$ ). The haver measures $4000 \mu \mathrm{m}(1600-5400)(n=13)$. The genital atrium (Figure 5a) opens ventrally, is formed by two globular muscular masses, and consists of 
a

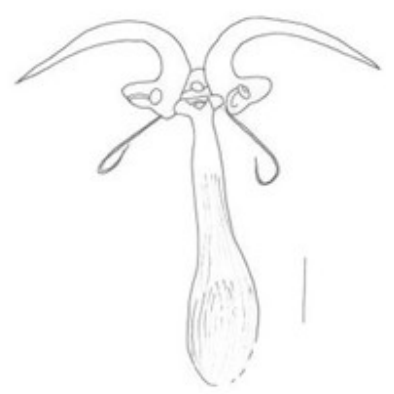

b

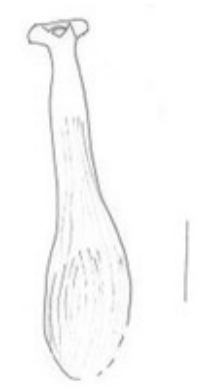

c

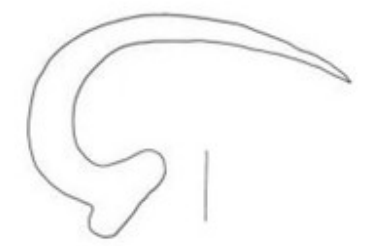

d

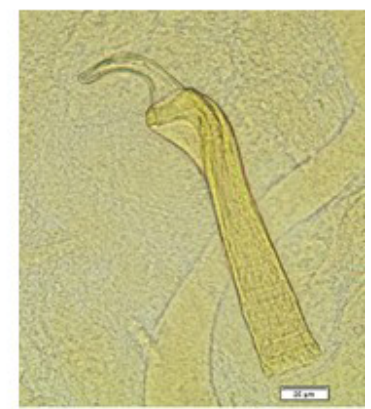

\section{e}

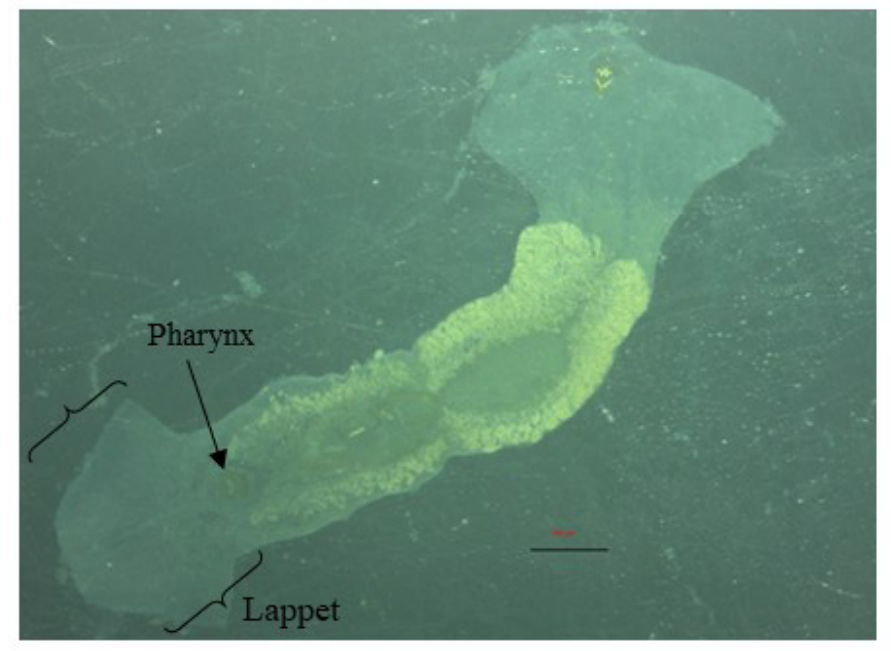

Scale bars: $20 \mu \mathrm{m}(\mathrm{a}-\mathrm{d}) ; 2.5 \mathrm{~mm}(\mathrm{e})$

Figure 3: Calceostoma glandulosum Johnston \& Tiegs, 1922 collected from gills of silver kob. (a) Haptor with median bar and hamuli. (b) Median bar. (c) Hamulus. (d) Male copulatory organ. (e) Whole mount.

two symmetrical continuous genital hamuliform spine rows (instead of three as described in the other two Sciaenacotyle species), parallel to each other (Figure 5a). These spinal rows of the genital atrium (Figure 5a and $5 \mathrm{c}$ ) interchange where they bend anteriorly with the longer outer spinal row coiling inwards at the anterior end and the shorter spinal row coiling outwards at the anterior end as they continue in a parallel manner. The genital hamuliform spines of the outer spiral rows increase toward the end of the row (Figure $5 b$ ). The hamuliform spine counts were 139 $(131-154)(n=5)$ in total number and measure length at posterior end $11 \mu \mathrm{m}(6-16)(n=5)$ (Figure 5d); mid-length $21 \mu \mathrm{m}(14-28)(n=5)$ (Figure $5 \mathrm{c})$ and length at anterior end $8 \mu \mathrm{m}(3-11)(n=5)$ (Figure $5 \mathrm{~b})$. Spines at the anterior end slightly curved compared to the spines at the posterior end, which are straight and also sharper. Spines at the middle of the row have a hook that is curved and a blade that is curved at almost $90^{\circ}$ (Figure 5c).

\section{Acanthocephalan}

\section{Corynosoma australe Johnston, 1937}

Host: Argyrosomus inodorus Griffiths and Heemstra, 1995

Site: Body cavity

Locality: Henties Bay, Mile 108 and Toscanini, Namibia

\section{Description:}

The measurements of $C$. australe in this study are not described separately for female and male individuals due to the small number of specimens measured, but, generally, males had more and longer genital spines than females. Measurements were done in relation to Sardella et al. ${ }^{25}$ Six whole-mount specimens were measured (3 males, 3 females). Total body length $3331 \mu \mathrm{m}$ (2867-3647) $(n=5)$ and maximum body width $1076 \mu \mathrm{m}$ (943-1211) (n=6) (Figure 6). Females possessed a relatively wider maximum body width than males. The spiny proboscis measures $556 \mu \mathrm{m}(356-712)(n=6)$ total length and $269 \mu \mathrm{m}(238-290)$ $(n=6)$ maximum width. Proboscis receptacle $1194 \mu \mathrm{m}$ (936-1339) $(n=5)$ total length and $276 \mu \mathrm{m}(227-331)(n=5)$ width. The neck, wider than long, total length $258 \mu \mathrm{m}$ (236-273) $(n=5)$ and maximum neck width $424 \mu \mathrm{m}(400-448)(n=5)$. Trunk length measures $2448 \mu \mathrm{m}$ (2063-2617) $(n=5)$ and is relatively longer in males than in females. The genital spines have a length of $32 \mu \mathrm{m}(18-45)(n=6)$ and mid-width of $14 \mu \mathrm{m}(7-21)(n=6)$. Only one of the three males had testes visible enough to make accurate measurement: right testes length $117 \mu \mathrm{m}$; right testes width $85 \mu \mathrm{m}$; left testes length $112 \mu \mathrm{m}$; and left testes width $88 \mu \mathrm{m}$.

\section{Discussion}

We have reported five parasite species from silver kob (A. inodorus): Diplectanum sciaenae, Calceostoma glandulosum, Calceostoma sp., Sciaenacotyle sp. and Corynosoma australe.

The morphological characteristics and measurements of $D$. sciaenae correspond with those described previously $y^{3,9,34}$ (Table 2). Diplectanids have been reported several times in aquaculture from all over the world, with increasing mortality in sciaenids, but they are not highly pathogenic parasites in nature. ${ }^{9}$ 
Table 2: Measurements $(\mu \mathrm{m})$ of Diplectanum Diesing, 1858 species from Argyrosomus hololepidotus, Argyrosomus regius and Argyrosomus inodorus

\begin{tabular}{|c|c|c|c|c|c|c|}
\hline Character & D. oliveria & D. glandulosum ${ }^{a}$ & D. dollfusib & D. bocquetib & D. sciaenae ${ }^{b}$ & D. sciaenae ${ }^{c}$ \\
\hline Host & A. hololepidotus & A. hololepidotus & A. regius & A. regius & A. regius & A. inodorus \\
\hline Body length & $909-1139$ & $499-640$ & $660-1370$ & $800-1230$ & $500-1160$ & $751(436-1066)$ \\
\hline Body width & $166-224$ & $128-154$ & $160-370$ & $240-370$ & $140-400$ & $165(79-250)$ \\
\hline Haptor width & $224-275$ & $243-269$ & $230-480$ & $120-400$ & $260-380$ & $252(198-310)$ \\
\hline Penis length & $166-179$ & $51-66$ & $57-78$ & $90-123$ & $51-94$ & $63(49-76)$ \\
\hline Canal length & - & - & - & - & - & $29(26-40)$ \\
\hline Canal width & - & - & - & - & - & $9(5-12)$ \\
\hline Squamodisc length & - & - & - & - & - & 173(124-222) \\
\hline Squamodisc width & $166-189$ & $99-106$ & $144-160$ & $120-160$ & $144-170$ & 148 (109-187) \\
\hline Concentric rows & - & - & $32-38$ & $26-32$ & $31-41$ & 35 (32-38) \\
\hline Median bar length & $128-158$ & $117-153$ & $108-159$ & $102-132$ & $95-150$ & $107(97-134)$ \\
\hline Median bar width & - & - & - & - & - & $23(19-27)$ \\
\hline Median bar $1 / 2$ width & - & - & - & - & - & $15(12-17)$ \\
\hline Transverse bar length & $96-110$ & $90-117$ & $92-146$ & $88-100$ & $88-100$ & $94(81-122)$ \\
\hline Ventral hamulus (a) & $67-77$ & $72-77$ & $87-94$ & $58-67$ & $69-79$ & 70 (64-74) \\
\hline Ventral hamulus (b) & - & $65-69$ & $78-86$ & $52-63$ & $63-73$ & $65(59-67)$ \\
\hline Ventral hamulus (c) & $32-34$ & 34 & $43-50$ & $27-32$ & $33-41$ & $37(34-40)$ \\
\hline Ventral hamulus (d) & $30-32$ & $30-32$ & $33-39$ & $25-32$ & $26-35$ & $28(25-33)$ \\
\hline Dorsal hamulus (a) & $66-70$ & $64-67$ & $83-89$ & $57-62$ & $62-68$ & $62(55-65)$ \\
\hline Dorsal hamulus (b) & $61-64$ & $59-64$ & $62-135$ & $51-56$ & $59-64$ & $57(52-60)$ \\
\hline
\end{tabular}

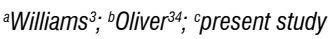

Table 3: Measurements $(\mu \mathrm{m})$ of Calceostoma glandulosum Johnston \& Tiegs, 1922, Calceostoma calceostoma Wagener, 1857 and Calceostoma sp. from Argyrosomus hololepidotus, Argyrosomus regius and Argyrosomus inodorus

\begin{tabular}{l|c|c|c|c|c}
\hline \hline Character & C. glandulosum & C. calceostoma & C. calceostoma & C. glandulosum & Calceostoma sp. \\
\hline Host & $\begin{array}{c}\text { A. hololepidotus } \\
\text { (Western Australia) }\end{array}$ & $\begin{array}{c}\text { A. regius } \\
\text { (Tunis) }\end{array}$ & $\begin{array}{c}\text { A. regius } \\
\text { (Gulf of Gascoigne) }\end{array}$ & $\begin{array}{c}\text { A. inodorus } \\
\text { (northern Namibia) }\end{array}$ & $\begin{array}{c}\text { A. inodorus } \\
\text { (northern Namibia) }\end{array}$ \\
\hline Total length & $2724(1848-4176)$ & $3295(2875-4002)$ & 6302 & $6250(4200-8000)$ & $46332900-6900)$ \\
\hline Max body width & $748(592-960)$ & $632(598-644)$ & $759-1012$ & $1000(900-1100)$ & $566(400-800)$ \\
\hline Lappet max width & $794(504-1296)$ & $776(644-897)$ & 943 & $1225(200-1900)$ & 2000 \\
\hline Pharynx length & $210(157-272)$ & $202(179-216)$ & $273(255-291)$ & $289(236-322)$ & $303(293-312)$ \\
\hline Pharynx width & $168(132-208)$ & $164(156-179)$ & - & $270(226-342)$ & $276(260-292)$ \\
\hline Median length & $238(243-236)$ & $178(154-207)$ & $239(230-251)$ & $225(219-233)$ & $146(132-172)$ \\
\hline Median max width & - & - & - & $50(44-53)$ & $36(32-39)$ \\
\hline Hamulus length & $129(112-139)$ & $94(71-106)$ & $135(124-147)$ & $199(188-213)$ & $143 .(128-159)$ \\
\hline Penis length (a) & 182 & $134(124-152)$ & $189(179-209)$ & $188(178-195)$ & $183(172-202)$ \\
\hline Penis length (b) & - & - & - & $165(159-171)$ & $138(124-153)$ \\
\hline Penis width & 23 & $14(12-14)$ & $19(14-23)$ & $24(21-26)$ & $12(11-13)$ \\
\hline Study & Williams & Williams & & This study & This study \\
\hline
\end{tabular}




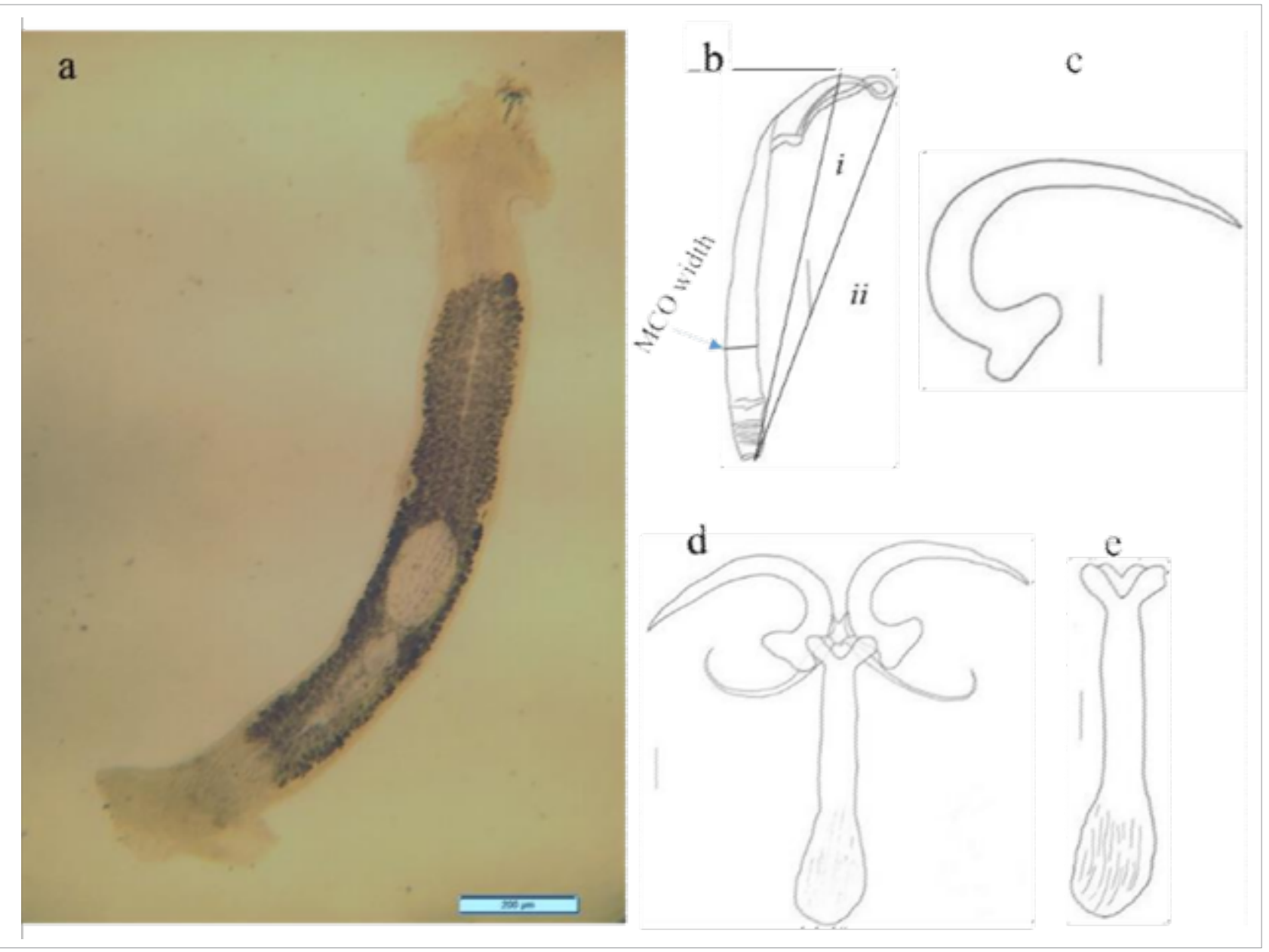

Scale bars: $20 \mu m(a-d) .2 .5 \mathrm{~mm}(e)$

Figure 4: Calceostoma sp. collected from stomach of silver kob. (a) Whole mount. (b) Male copulatory organ. (c) Hamulus. (d) Haptor with median bar and hamuli. (e) Median bar.

Calceostoma glandulosum in the present study was longer and wider than described by Williams ${ }^{3}$ (Table 3). The reason could be due to stretching of the parasites during mounting on the slides, as monogeneans were fixed without coverslip pressure. Williams ${ }^{3}$ also found that Calceostoma calceostoma in Argyrosomus regius from Tunis differed in size (were smaller) compared to Calceostoma calceostoma Wagener, 1857 in Argyrosomus regius from the Gulf of Gascogne. This means that Calceostoma species may vary according to their geographical distribution with different physical and chemical environmental parameters.

A calceostomatid Calceostoma sp., possessing morphological characteristics almost similar to an undescribed Calceostoma sp. found by Stewart ${ }^{21}$ from the gills of Argyrosomus inodorus, was found in the stomach of $A$. inodorus. Stomach dactylogyrid monogeneans such as Enterogyrus Paperna, 1963 have been documented on freshwater fish by Bayoumy and El-Monem ${ }^{35}$ and others, but they possess different haptoral and copulatory characteristics that enable them to adapt to the internal environment of their fish hosts. This is the first case of a calceostomatid in the gastrointestinal organs of marine species and more studies are necessary to understand the differences and/or similarities between these two species as well as their parasitic behaviours and pathogenic characteristics.

It could be assumed that because these $A$. inodorus feed on small pelagic fish (mostly sardine based on their gut content), the monogenean parasites could have survived from the gills of sardine (Sardinops sp.) into the stomach of $A$. inodorus during ingestion. To test this hypothesis, the inspection of sardine gills is required to confirm whether Calceostoma $\mathrm{sp}$. infest the gills of sardine. Only one or two individual Calceostoma sp. were found in every infected $A$. inodorus host. These may have been individuals that 'luckily' managed to survive the new environment of the stomach, despite being morphologically adapted to live and reproduce on the gills. The life cycle of a monogenean involves a free-living ciliated larva, called oncomiracidium. ${ }^{34,36}$ Chances are that a few parasites of Calceostoma sp. accumulated from the aquatic environment when fish were feeding and very few individuals managed to survive at the

Table 4: Measurements $(\mu \mathrm{m})$ of Sciaenacotyle sp. from Argyrosomus inodorus from northern Namibia

\begin{tabular}{l|c|c|c}
\hline \hline Character & Mean & Minimum & Maximum \\
\hline Body length & 8123 & 4000 & 11400 \\
\hline Body width & 1208 & 500 & 1800 \\
\hline Tail length & 4000 & 1600 & 5400 \\
\hline Genital spine rows & 2 & 2 & 2 \\
\hline No. of hamuliform spines & & & \\
\hline \multicolumn{1}{|r|}{ Row 2 } & 139 & 131 & 154 \\
\hline Length at posterior end & 11 & 148 & 163 \\
\hline Mid-length & 21 & 14 & 16 \\
\hline Length at anterior end & 8 & 3 & 28 \\
\hline
\end{tabular}




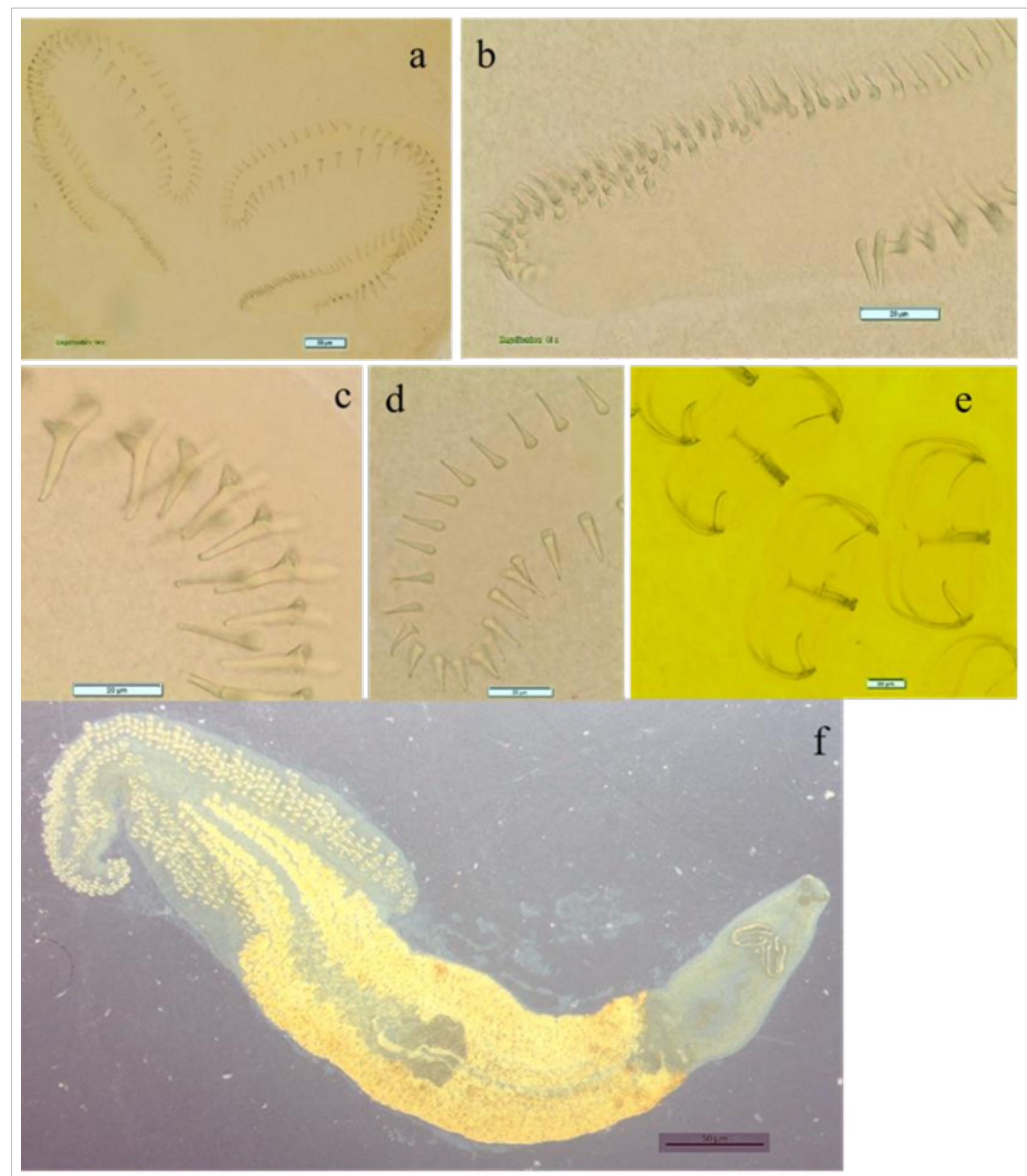

Figure 5: Sciaenacotyle sp. collected from the gills of silver kob. (a) Genital atrium. (b) Genital anterior end hamuliform spines. (c) Genital mid hamuliform spines. (d) Genital posterior end hamuliform spines. (e) Clamps. (f) Whole mount.

threshold of the stomach walls, where all these parasites were recovered. More studies, including molecular work on Calceostoma species from the gills, previously described ${ }^{33}$, and Calceostoma sp. from the stomach, are therefore required to supplement the similarities described in this study, explain the survival of this parasite and understand the unusual adaptive mechanism of this gill monogenean parasite, which allows it to survive in the stomach of its $A$. inodorus host.

The microcotylid Sciaenacotyle sp. in the present study differed in makeup of their genital atrium from the other two Sciaenacotyle species, S. sciaenicola ${ }^{5}$ and $S$. panceri ${ }^{6,23}$, previously described. The two species possess a genital atrium consisting of three genital spine rows. However, the microcotylid in the present study possessed a genital atrium consisting of two genital spine rows. In addition, Sciaenacotyle sp. has more genital spines with a smaller minimum length than those described for the two previously described species (Table 4).

Sardella et al. ${ }^{25}$ showed that adult $C$. australe differed in size from different hosts (seal Arctocephalus australis and fish hosts Corynoscion quatucupa). Corynosoma australe from the present study were larger than those formerly described. ${ }^{14}$ They also possessed longer proboscis, neck and truck lengths (Table 5). 
Table 5: Measurements $(\mu \mathrm{m})$ of Corynosoma australe Johnston, 1937 from Arctocephalus australis, Cynoscion guatucupa and Argyrosomus inodorus

\begin{tabular}{|c|c|c|c|}
\hline Host & A. australis ${ }^{\mathrm{a}}$ & C. guatucupa $\mathrm{a}^{\mathrm{a}}$ & A. inodorus ${ }^{b}$ \\
\hline Body L (length) & $4200-5500$ & $2560-3180$ & 3331 (2867-3647) \\
\hline Body W (width) & $1300-1620$ & $760-1140$ & $1076(943-1211)$ \\
\hline Proboscis L & $580-740$ & $580-740$ & 556 (356-712) \\
\hline Proboscis W & $210-250$ & $180-280$ & $269(238-290)$ \\
\hline Neck L & $160-260$ & $19-270$ & $258(236-273)$ \\
\hline Neck max W & $360-500$ & $260-420$ & 424 (400-448) \\
\hline Truck L & $3420-4660$ & $1640-2180$ & 2448 (2063-2617 \\
\hline Genital spines L & $25-48$ & $31-48$ & 32 (24-39) \\
\hline Genital spines W & $8.0-29$ & $8.0-27$ & $14(9-17)$ \\
\hline $\begin{array}{l}\text { Proboscis } \\
\text { receptacle L }\end{array}$ & $740-1040$ & $860-1300$ & $1194(936-1390)$ \\
\hline $\begin{array}{l}\text { Proboscis } \\
\text { receptacle W }\end{array}$ & $140-200$ & $140-280$ & $276(227-331)$ \\
\hline Right testes $\mathrm{L}$ & $440-700$ & $100-140$ & 117 \\
\hline Right testes W & $260-420$ & $80-120$ & 85 \\
\hline Left testes $\mathrm{L}$ & $400-660$ & $110-140$ & 112 \\
\hline Left testes W & $280-420$ & $80-120$ & 88 \\
\hline
\end{tabular}

${ }^{a}$ Sardella et al. ${ }^{25}$; present study
This is the first descriptive study of parasites of $A$. inodorus in Namibia. More studies are required to complement the findings. The presence of parasites from $A$. inodorus hosts highlights the need for further surveillance of the health of fish, especially when used in an aquaculture set-up. ${ }^{5}$

Results from this study are also a significant tool towards stock identification, which is a key component for the management of economically important fish species. They will contribute to and improve the understanding of the vulnerability of unequally exploited subpopulations within the $A$. inodorus species range and thus help with the implementation of sustainable fisheries practices. ${ }^{37}$ Biological tags used for stock identification is significant research given the rise in global fisheries as more species are being targeted and commercially exploited to keep up with the increasing demand. ${ }^{38}$ Many natural tags have been used in population structure studies but parasites as biological tags have gained wide acceptance in recent decades as they can provide a reliable guide to understanding the biology of the hosts. ${ }^{39}$ Parasites as biological tags for stock identification have not been used in Namibia, but they have been used successfully in South Africa to identify between two hake species (Merluccius capensis Castelnau, 1861 and Merluccius paradoxuc Franca, 1960) ${ }^{40}$ and recently for sardine species (Sardinops sagax Jenyns, 1842) ${ }^{41}$. This study will significantly add to that resource and create a threshold for more studies on $A$. inodorus and other marine fish species.

\section{Acknowledgements}

We acknowledge a NAMSOV fellowship from the University of Namibia for funding the study. This work was supported by the South African Research Chairs Initiative (SARChl) of the Department of Science and Innovation and National Research Foundation of South Africa. Any opinion, finding and conclusion or recommendation expressed in this material is that of the authors and the NRF does not accept any liability in this regard.

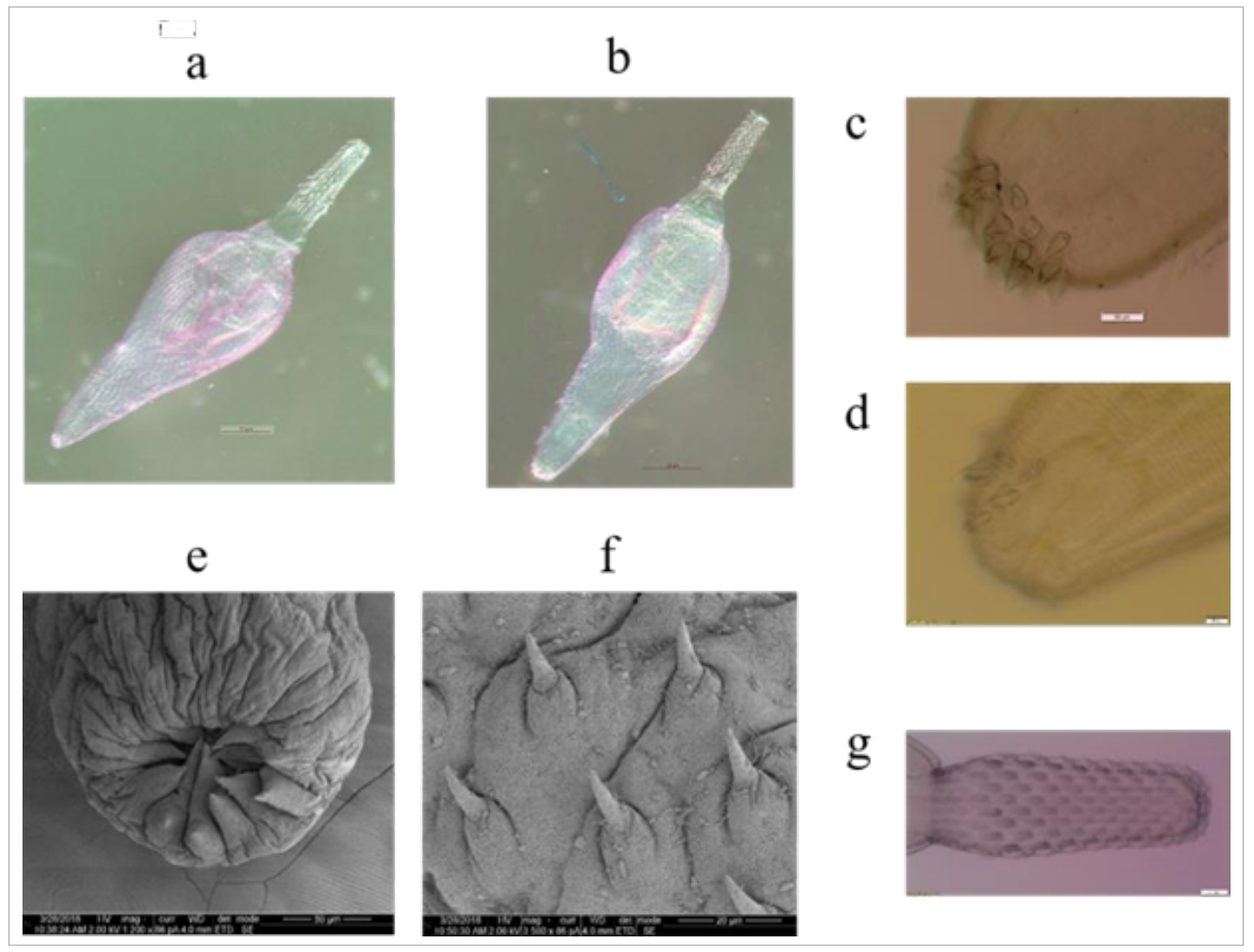

Figure 6: Corynosoma australe Johnston, 1937 collected from the body cavity of silver kob. (a) Female and (b) male. (c) Male and (d) female genital spines of adult $C$. australe. (e) Scanning electron micrograph (SEM) of spines at the folded in neck of $C$. australe. (f) SEM of spines. (g) Proboscis of adult $C$. australe, notice hooks. 


\section{Competing interests}

We have no competing interests to declare.

\section{Authors' contributions}

A.M.A.: Methodology, data collection, data analysis, writing - the initial draft, writing - revisions. A.H.: Student supervision, project leadership, validation. M.J.W.: Student supervision, project leadership, validation. M.T.: Student supervision, methodology, data collection. R.H.: Validation. W.L.-P.: Student supervision, funding acquisition, validation.

\section{References}

1. Griffiths MH. The taxonomy and life-history of Argyrosomus japonicus and $A$. inodorus, two important sciaenids off the South African coast [PhD thesis]. Makhanda: Rhodes University; 1995.

2. Griffiths MH. The life history and stock separation of silver kob, Argyrosomus inodorus, in South African waters. Oceanogr Lit Rev. 1997;11(44):13581359.

3. Williams A. Some monogenean parasites of the genera Calceostoma van Beneden, 1852 and Diplectanum Diesing, 1858 from Argyrosomus hololepidotus (Lacepède, 1802) (Sciaenidae: Teleostei) in Western Australia. Syst Parasitol. 1989;14(3):187-201. https://doi.org/10.1007/bf02187053

4. Grab DJ. Parasitological Society of Southern Africa. J S Afr Vet Assoc. 2005;76(3):172-183. https://doi.org/10.4102/jsava.v76i3.421

5. Hayward CJ, Bott NJ, Itoh N, Iwashita M, Okihiro M, Nowak BF. Three species of parasites emerging on the gills of mulloway, Argyrosomus japonicus (Temminck and Schlegel. 1843), cultured in Australia. Aquaculture. 2007;265(1-4):27-40. https://doi.org/10.1016/j.aquaculture.2007.04.080

6. Merella P, Cherchi S, Garippa G, Fioravanti ML, Gustinelli A, Salati F. Outbreak of Sciaenacotyle panceri (Monogenea) on cage-reared meagre Argyrosomus regius (Osteichthyes) from the western Mediterranean Sea. Dis Aquat Org. 2009;86(2):169-173. https://doi.org/10.3354/da002115

7. Hutson KS, Catalano SR, Whittington ID. Metazoan parasite survey of selected macro-inshore fish of southeastern Australia, including species of commercial importance. No. 2007/225. Townsville: James Cook University; 2011.

8. Oliva ME, Valdivia IM, Chavez RA, Molina H, Cárdenas L. Molecular and morphological evidence demonstrating two species of Helicometrina Linton 1910 (Digenea: Opecoelidae) in Northern Chile. J Parasitol. 2015;101 (6):694700. https://doi.org/10.1645/14-523

9. Andree KB, Roque A, Duncan N, Gisbert E, Estevez A, Tsertou Ml, et al. Diplectanum sciaenae (Van Beneden \& Hesse. 1863) (Monogenea) infecting meagre, Argyrosomus regius (Asso. 1801) broodstock in Catalonia, Spain. A case report. Vet Parasitol Reg Stud Reports. 2015;1:75-79. https://doi. org/10.1016/j.vprsr.2016.02.006

10. Costa JZ, McCarthy Ú, Perez 0 , Ramos E, Rodriguez M, Monterroso 0, et al. Occurrence of Photobacterium damselae subsp. Piscicida in sea-cage farmed meagre (Argyrosomus regius) in Tenerife, Canary Islands, Spain. Int J Mar Sci. 2017;33(1):65-71. https://doi.org/10.1007/s41208-017-0022-5

11. Kirchner $\mathrm{CH}$, Stage J. An economic comparison of the commercial and recreational line fisheries in Namibia (No. 71). Windhoek: Directorate of Environmental Affairs, Ministry of Environment and Tourism; 2005.

12. Tjipute M. Feasibility study for mass production of the silver kob, Argyrosomus inodorus, in Namibia. Reykjavík: United Nations University - Fisheries Training Programme; 2011.

13. Iwanowicz DD. Overview on the effects of parasites on fish health. In: Proceedings of the Third Bilateral Conference between Russia and the United States: Bridging America and Russia with shared perspectives on aquatic animal health. Landover, MD: Khaled bin Sultan Living Oceans Foundation; 2011. p. 176-184.

14. Woo PT, Gregory DWB, editors. Diseases and disorders of finfish in cage culture. Wallingford: CABI; 2014. https://doi. org/10.1079/9781780642079.0000

15. Labella A, Berbel C, Manchado M, Castro D, Borrego JJ. Photobacterium damselae subsp. damselae, an emerging pathogen affecting new cultured marine fish species in southern Spain. In Recent advances in fish farms. Malaga: Institution of Technology; 2011. https://doi.org/10.5772/26795
16. Bruno DW, Noguera PA, Poppe TT. A colour atlas of salmonid diseases. Vol. 91. Aberdeen: Springer Science \& Business Media; 2013. https://doi. org/10.1007/978-94-007-2010-7

17. Rohde K, Rohde PP. The ecological niches of parasites. In: Rohde K, editor. Marine Parasitology. Wallingford: CABl; 2005. p. 286-293. https://doi. org/10.1079/9780643090255.0000

18. Martins ML, Cardoso L, Marchiori N, Benites de Pádua S. Protozoan infections in farmed fish from Brazil: Diagnosis and pathogenesis. Rev Bras DE Parasito Vet. 2015;24(1):1-20. https://doi.org/10.1590/s1984-29612015013

19. Kotob MH, Menanteau-Ledouble S, Kumar G, Abdelzaher M, El-Matbouli M. The impact of co-infections on fish: A review. Vet Res. 2017;47(1):98. https://doi.org/10.1186/s13567-016-0383-4

20. Poulin R. The functional importance of parasites in animal communities Many roles at many levels? Int J Parasitol. 1999;29(6):903-914. https://doi. org/10.1016/s0020-7519(99)00045-4

21. Stewart KA. Embryonation and efficacy of treatments on monogenean gill flukes infecting silver kob (Argyrosomus inodorus) [PhD thesis]. Cape Town: University of Cape Town; 2005

22. Gibson DI, Bray RA. Diplectanum Diesing, 1858. In: Tyler S, Artois T, Schilling $\mathrm{S}$, Hooge M, Bush LF, editors. World list of platyhelminthes [webpage on the Internet]. c2010 [cited 2018 0ct 13]. Available from: http://www. marinespecies.org/aphia.php? $p=$ taxdetails\&id $=119291$

23. Ktari MH. Microcotyle panceri Sonsino, 1891 (Monogenea - Microcotylidae) parasite d'Umbrina cirrhosa L. dans le golfe de Tunis [Microcotyle panceri Sonsino, 1891 (Monogenea - Microcotylidae) parasite of Umbrina cirrhosa $\mathrm{L}$ in the Gulf of Tunis]. Bull Inst Natl Sci Tech Océanogr Pêche Salammbô. 1970;1:169-180. French.

24. Amin OM. Classification of the Acanthocephala. Folia Parasitologica 2013;60(4):273-305. https://doi.org/10.14411/fp.2013.031

25. Sardella NH, Mattiucci S, Timi JT, Bastida R0, Rodríguez DH, Nascetti G. Corynosoma australe Johnston, 1937 and C. cetaceum Johnston \& Best, 1942 (Acanthocephala: Polymorphidae) from marine mammals and fishes in Argentinian waters: Allozyme markers and taxonomic status. Syst Parasitol. 2005;61(2):143-156. https://doi.org/10.1007/s11230-005-3131-0

26. Ionita M, Varela MG, Lyons ET, Spraker TR, Tolliver SC. Hookworms (Uncinaria lucasi) and acanthocephalans (Corynosoma spp. and Bolbosoma spp.) found in dead northern fur seals (Callorhinus ursinus) on St. Paul Island, Alaska in 2007. Parasitol Res. 2008;103(5):1025. https://doi.org/10.1007/ s00436-008-1087-0

27. Silva RZ, Pereira J, Cousin JCB. Histological patterns of the intestinal attachment of Corynosoma australe (Acanthocephala: Polymorphidae) in Arctocephalus australis (Mammalia: Pinnipedia). J Parasit Dis. 2014;38(4):410-416. https://doi.org/10.1007/s12639-013-0250-4

28. Hayunga EG. Morphological adaptations of intestinal helminths. J Parasitol. 1991;77(6):865-873. https://doi.org/10.1007/s12639-013-0250-4

29. MacKenzie K, Abaunza P, Campbell N. The use of parasites as biological tags in multidisciplinary stock identification studies of small pelagic fish. Aberdeen: School of Biological Sciences (Zoology), University of Aberdeen; 2005.

30. Marcogliese DJ. Food webs and the transmission of parasites to marine fish. Parasitology. 2002;124(7):83-99. https://doi.org/10.1017/ s003118200200149x

31. Christison KW, Ottob H, Moutonc A. Screening of 4 anthelminthics for their efficacy against the gill-parasitising monogeneans Calceostoma sp. and Diplectanum sp. from the silver kob, Argyrosomus inodorus. (Abstract). Tydskr S Afr Vet Ver. 2005;76(3):172-183.

32. Noga EJ. Fish disease: Diagnosis and treatment. Raleigh, NC: John Wiley \& Sons; 2010. https://doi.org/10.1002/9781118786758

33. Amakali AM. Ecto- and endo-parasites of silver kob (Argyrosomus Inodorus) from northern Namibia $\left(21^{\circ}-24^{\circ} \mathrm{S}\right)$ [thesis]. Windhoek: University of Namibia; 2019.

34. Oliver G. Les Diplectanidae Bychowsky, 1957 (Monogenea, Monopisthocotylea) parasites des Sciaenidae (Pisces, Perciformes) du Golfe de Gascogne [(Diplectanidae Bychowsky, 1957 (Monogenea, Monopisthocotylea) parasites of the Sciaenidae (Pisces, Perciformes) of the Bay of Biscay]. Bull Mus natl hist nat Écol gén. 1980;3:669-689. French. https://doi.org/10.1111/j.1463-6409.1984.tb00035.x 
35. Bayoumy EM, EI-Monem SA. Functional adaptation of branchial and stomach dactylogyrid monogenean: Cichlidogyrus and Enterogyrus isolated from Oreochromis niloticus. In: Proceedings of the 5th Global Fisheries and Aquaculture Research Conference; 2012 October 1-3; Giza, Egypt. p. 353-360.

36. Whittington ID, Chisholm LA, Rohde K. The larvae of Monogenea (Platyhelminthes). Adv Parasitol. 1999;44:139-232. https://doi.org/10.1016/ s0065-308x(08)60232-8

37. Whittington ID, Kearn GC. Hatching strategies in monogenean (Platyhelminth) parasites that facilitate host infection. Integr Comp Biol. 2011;51(1):91-99. https://doi.org/10.1093/icb/icr003
38. Klapper R, Kochmann J, O'Hara RB, Karl H, Kuhn T. Parasites as biological tags for stock discrimination of beaked redfish (Sebastes mentella): Parasite infra-communities vs. limited resolution of cytochrome markers. PLOS ONE. 2016;11(4), e0153964. https://doi.org/10.1371/journal.pone.0153964

39. Catalano SR, Whittington ID, Donnellan SC, Gillanders BM. Parasites as biological tags to assess host population structure: Guidelines, recent genetic advances and comments on a holistic approach. Int J Parasitol Parasites Wildl. 2014;3(2):220-226. https://doi.org/10.1016/j.ijppaw.2013.11.001

40. Botha L. Major endoparasites of the Cape hakes Merluccius capensis and M. paradoxus, with brief notes on some conspicuous ectoparasites. Afr J Mar Sci. 1986;4(1):45-49. https://doi.org/10.1016/j.ijppaw.2013.11.001

41. Reed C, MacKenzie K, Van der Lingen CD. Parasites of South African sardines, Sardinops sagax, and an assessment of their potential as biological tags. Bull Eur Assoc Fish Pathol. 2012;32(2):41-48. 